\title{
Combination of mineral and organic fertilizers of slaughterhouse-waste products for cultivation of upland rice cultivars
}

\author{
José Roberto Portugal ${ }^{1}$, Orivaldo Arf ${ }^{1}$, Ricardo Antônio Ferreira Rodrigues ${ }^{2}$, Rafael Gonçalves Vilela ${ }^{3}$, Alex \\ Rangel Gonzaga ${ }^{1}$, Amanda Ribeiro Peres ${ }^{2}$, Douglas de Castilho Gitti ${ }^{4}$, Daiene Camila Dias Chaves Corsini ${ }^{1}$ \\ ${ }^{1}$ São Paulo State University (UNESP), Department of Plant Science, Food Technology and Social Economy, Ilha \\ Solteira, State of São Paulo, Brazil \\ ${ }^{2}$ São Paulo State University (UNESP), Department of Plant Health, Rural Engineering and Soil, Ilha Solteira, State of \\ São Paulo, Brazil \\ ${ }^{3}$ Chapadão Foundation, Chapadão do Sul, State of Mato Grosso do Sul, Brazil \\ ${ }^{4} \mathrm{MS}$ Foundation, Maracaju, State of Mato Grosso do Sul, Brazil
}

\section{*Corresponding author: jrp.agrunesp@gmail.com}

\begin{abstract}
Due to the expansion of the slaughterhouses sector, there is huge availability of waste from agricultural products. These waste products may be used as alternative for the production of organic fertilizers. Fertilizer efficiency depends on the type of rice cultivar. Thus, traditional, intermediate and modern plant types may respond differently to the combined use of mineral and organic fertilizers. The objective of this study is to evaluate the effects of different combinations of mineral and organic fertilizers based on slaughterhouse waste on the development, productivity and industrial quality of upland rice cultivars. The soil of the the experimental area was a typical clayey dystroferric Red Latosol and the climate of the region is Aw: humid tropical, rainy in the summer and dry in the winter according to the Koppen classification. The experimental design was randomized blocks arranged in a $3 \times 6$ factorial design. We evaluated three different types of rice cultivars (Caiapó, traditional type; BRS Primavera, intermediate type; and IAC 202, modern type) and levels of combinations of mineral and organic fertilizers ( $100 \%$ mineral, $80 \%$ mineral $+20 \%$ organic, $60 \%$ mineral $+40 \%$ organic, $40 \%$ mineral $+60 \%$ organic, $20 \%$ mineral $+80 \%$ organic, $100 \%$ organic). The cultivar IAC 202 presented a productive potential higher than the cultivars Caiapó and BRS Primavera. The $60 \%$ mineral $+40 \%$ organic and $40 \%$ mineral $+60 \%$ organic fertilizer combinations produced more yield in comparison with the $100 \%$ organic fertilizer. The cultivar Caiapó showed the highest grain quality. Organic fertilizer based on slaughterhouse waste can be used for upland rice farming.
\end{abstract}

Keywords: Oryza sativa L., fertilizer, fridge waste, rice plant, Cerrado.

Abbreviations: a.i._. active ingrediente; $\mathrm{DAE}_{-}$days after emergence; $\mathrm{Kc}_{-}$crop coefficients; $\mathrm{K}_{2} \mathrm{O} \_$potassium oxide; $\mathrm{N}_{-}$nitrogênio; $\mathrm{P}_{2} \mathrm{O}_{5} \_$phosphorus pentoxide

Introduction

Rice (Oryza sativa L.) is the main food of approximately 3.5 billion people, representing almost half of the world population (Mohanty, 2013). In the region comprising Latin America and the Caribbean, Brazil is responsible for $65 \%$ of the total rice production, $52 \%$ of all irrigated rice and $92 \%$ of all upland rice. The area cultivated with upland rice in Brazil represents $62 \%$ (Grisp, 2013). However, it accounts for only $21 \%$ of the total production (Ferreira and Santiago, 2012). This is because the average grain yield of this system is considered low, i.e., $1,824 \mathrm{~kg} \mathrm{ha}^{-1}$, approximately three times lower than the productivity of rice using the flooded system (Ferreira and Santiago, 2012).

In Brazil, several researchers have been studying factors that could increase the productivity of upland rice, especially in the Cerrado, a region where rice cultivation can be introduced to integrate the crop rotation system. Among the most studied factors the mineral fertilization with nitrogen (Arf et al., 2005; Cazetta et al., 2008; Hernandes et al., 2010;
Gitti et al., 2012; Artigiani et al., 2012; Arf et al., 2015; Silva et al., 2016), phosphorus (Tokura et al., 2007; Garcia et al., 2009; Rotili et al., 2010; Fidelis et al., 2013), potassium (Fageria, 2000; Silva et al., 2002; Zaratin et al., 2004; Barbosa Filho et al., 2006), and nitrogen, phosphorus and potassium (Crusciol et al., 2003; Guimarães and Stone, 2004; Dias et al., 2010; Yamashita et al., 2013; Soares et al., 2015) are evident. However, there are few studies using organic fertilizers on upland rice in Brazil and in the world. Such studies should be encouraged.

Mineral fertilizer combined with organic fertilizer may provide a better crop productivity and an improved soil health (Imade et al., 2015). Over 295 million cattle were slaughtered in the world in 2012 (FAO, 2012). During the same year, Brazil accounted for approximately $10 \%$ of this amount, in which 31 million cattle slaughtered (IBGE, 2012). In that year, the Brazilian industrial refrigeration sector generated more than 900 thousand tons of bovine rumen, which is the main waste produced. To avoid environmental 
damage, this waste can be recycled and used as a fertilizer for crops (Nunes et al., 2015). Brazil, as one of the main producers of cattle beef in the world, presents a great potential for the use of slaughterhouse waste as organic fertilizer.

An adequate management of fertilization is essential to increase rice productivity (Che et al., 2016). However, research shows that an efficient use of nutrients by rice is influenced by the type of cultivar (Crusciol et al., 2016). Traditional cultivars such as Caiapó are tall and susceptible to lodging (Arf et al., 2012) but provide high 100 grains mass (Arf et al., 2012; Boldieri et al., 2010), a low tillering potential (Alvarez et al., 2012), and produce relatively well in low soil fertility (Fidelis et al., 2013). Modern cultivars, such as IAC 202 are short and resistant to lodging (Arf et al., 2012), present a high number of spikelets per panicle, a low one hundred grains mass (Boldieri et al., 2010), a high tillering potential (Alvarez et al., 2012), and are more responsive to fertilization (Crusciol et al., 2012; Pavinato et al., 2009). Intermediate cultivars such as BRS Primavera are medium-sized but may be susceptible to lodging (Arf et al., 2012; Fidelis et al., 2013) and present an average 100 grains mass (Soares et al., Boldieri et al., 2010) and an average tillering potential (Breseghello et al., 1998).

Little is known about the use of mineral fertilizers combined with organic fertilizers on upland rice cultivars. Upland rice cultivars may respond differently to combinations of mineral and organic fertilizers. Organic fertilizers based on slaughterhouse waste may replace part of the mineral fertilizer used for upland rice. Thus, the objective of this study is to evaluate the effects of different combinations of mineral and organic fertilizers based on slaughterhouse waste on the development, productivity and industrial quality of upland rice cultivars.

\section{Results and Discussion}

\section{Climate aspects and development}

Fig 1 ( $a$ and $b$ ) shows the mean values for rainfall and maximum and minimum temperatures during the conduction of the experiments in the two agricultural years (2009/10 and 2010/11). During the 2009/10, there was a cumulative rainfall of $68 \mathrm{~mm}$ between the sowing and the emergence from the emergence to the harvest and the total rainfall was $748 \mathrm{~mm}$. It is noteworthy that during the grain filling phase, there were less rainfalls. The water requirement of plants was supplemented by sprinkler irrigation. In 2010/11, the rainfall was $110 \mathrm{~mm}$ between sowing and plant emergence and $1,100 \mathrm{~mm}$ between emergence and harvest. There was a good distribution of rainfall throughout the vegetative phase. Only during the grain filling and maturing phases, there was an excess of consecutive rains. Rainfall values were consistent with the requirements for each stage of the crop. According to Fornasieri Filho and Fornasieri (2006) and Stone et al. (2015), rice crops require 600 to $700 \mathrm{~mm}$ of water during their life cycle. The average minimum temperature during the rice cycle was $21.6^{\circ} \mathrm{C}$ and the average maximum temperature was $31.9^{\circ} \mathrm{C}$ in $2009 / 10$. In 2010/11, temperatures were 21.1 and $31.7 \circ \mathrm{C}$ (average minimum temperature and average maximum temperature, respectively). Such temperatures are considered adequate for the crop development.
According to Yoshida (1981), the optimum temperature for rice cultivation is between 20 and 35 ㅇ․

In the first cultivation year, the cultivars Caiapó, BRS Primavera and IAC 202 flowered at 76, 72 and 75 DAE (days after emergence), respectively. In the second year, the cultivar Caiapó flowered at $89 \mathrm{DAE}$, the cultivar BRS Primavera at 86 DAE and the cultivar IAC 202 at 88 DAE. The harvesting of the three cultivars and the different combinations of mineral and organic fertilizers was performed at 100 and 114 DAE in the first and the second year, respectively.

\section{Plant height, lodging, number of panicle per $\mathrm{m}^{2}$ and number of spikelets per panicle}

Considering the cultivation year 2009/10, the cultivar Caiapó had the highest plant height, followed by BRS Primavera and IAC 202 (Table 1). During 2010/11, the cultivar Caiapó also showed a higher plant height, when compared to BRS Primavera and IAC 202. Regarding plant lodging (Table 1) cultivar Caiapó showed superiority during 2009/10. Both plant height and lodging were influenced only by the cultivar type. This is due to the type of plant of each cultivar: Caiapó: traditional (Soares et al., 1993), BRS Primavera: intermediate (Breseghello et al., 1998) and IAC 202: modern (Bastos, 2000). According to Colombari Filho and Rangel (2015), tall plants are more susceptible to lodging than short plants, because tall panicles cause a strong movement at the base of the stem.

Arf et al. (2012), studied growth and regulator doses of upland rice cultivars and reported cultivar Caiapó $(150 \mathrm{~cm})$ as taller plant, followed by BRS Primavera $(136 \mathrm{~cm})$ and IAC $202(116 \mathrm{~cm})$ without using any growth regulators. The authors reported a great lodging of plants for the cultivars Caiapó and BRS Primavera, and the absence of lodging for the cultivar IAC 202. Some authors reported a higher height for the cultivar Caiapó compared to the cultivar BRS Primavera (Moura Neto et al., 2002; Nascente et al., 2013). Some others reported a higher plant height for the cultivar Caiapó compared to the cultivar IAC 202 (Arf et al., 2000), a lower height for the cultivar IAC 202 followed by BRS Primavera, and a higher height for the cultivar Caiapó (Soares et al., 2003).

By analyzing the number of panicles per $\mathrm{m}^{2}$ (Table 1 ), we verified that there was an interaction between the cultivar and the fertilizer during the year 2009/10. The unfolding of interactions is shown in Table 2. For the cultivar Caiapó, we observed a higher number of panicles per $\mathrm{m}^{2}$ using the $20 \%$ mineral $+80 \%$ organic fertilizer than using $100 \%$ mineral, $60 \%$ mineral $+40 \%$ organic and $40 \%$ mineral $+60 \%$ organic fertilizers. The cultivar Caiapó is traditional and characterized by an average tillering (Breseghello et al., 1998). The number of panicles is directly related to tillering performance (Colombari Filho and Rangel 2015; Yoshida, 1981). Plants with such characteristics have a large root system (Morais et al., 1983). Thus, the roots of Caiapó plants can exploit a great soil volume and be better efficient in using nutrients in combination with a high amount of organic fertilizer ( $20 \%$ mineral $+80 \%$ organic) due to the slow release of nutrients.

The combination of $80 \%$ mineral $+20 \%$ organic fertilizer resulted in the highest number of panicles per $\mathrm{m}^{2}$ for the cultivar IAC 202 (291), and was not different with combination of $40 \%$ mineral $+60 \%$ organic (253) only. 
Table 1. Average values of plant height, lodging, number of panicle per $\mathrm{m}^{2}$ and number of spikelets per panicle obtained in upland rice cultivars as a function of combinations of mineral and organic fertilizer, Selvíria (MS), 2009/10 and 2010/11.

\begin{tabular}{|c|c|c|c|c|c|c|c|c|}
\hline \multirow{3}{*}{ Treatments } & \multicolumn{2}{|l|}{ Plant height } & \multicolumn{2}{|l|}{ Lodging $^{1}$} & \multicolumn{2}{|c|}{ Panicle per $\mathrm{m}^{-2}$} & \multicolumn{2}{|c|}{ Spikelets } \\
\hline & \multicolumn{4}{|l|}{$\mathrm{cm}$} & \multicolumn{2}{|c|}{ № } & \multicolumn{2}{|c|}{ № } \\
\hline & $09 / 10$ & $10 / 11$ & $09 / 10$ & $10 / 11$ & $09 / 10$ & $10 / 11$ & $09 / 10$ & $10 / 11$ \\
\hline \multicolumn{9}{|l|}{ Cultivars (C) } \\
\hline Caiapó & $138 \mathrm{a}$ & $111 \mathrm{a}$ & $3.8 a^{2}$ & 0 & 198 & $163 \mathrm{~b}$ & $164 \mathrm{~b}$ & $146 \mathrm{~b}$ \\
\hline Primavera & $122 \mathrm{~b}$ & $97 \mathrm{~b}$ & $0.0 \mathrm{~b}$ & 0 & 187 & $166 a b$ & $200 \mathrm{a}$ & $173 \mathrm{~b}$ \\
\hline IAC 202 & $104 \mathrm{c}$ & $101 \mathrm{~b}$ & $0.0 \mathrm{~b}$ & 0 & 250 & 183 a & $203 a$ & $228 a$ \\
\hline \multicolumn{9}{|c|}{ Combination of mineral and organic fertilizer (CF) } \\
\hline $100 \% \mathrm{M}$ & 124 & 102 & 1.4 & 0 & 196 & 161 & 196 & 163 \\
\hline $80 \% M+20 \% O$ & 123 & 104 & 1.4 & 0 & 228 & 174 & 197 & 197 \\
\hline $60 \% M+40 \% O$ & 122 & 105 & 1.0 & 0 & 209 & 178 & 193 & 181 \\
\hline $40 \% M+60 \% O$ & 120 & 101 & 1.0 & 0 & 207 & 178 & 185 & 170 \\
\hline $20 \% M+80 \% O$ & 118 & 101 & 1.2 & 0 & 222 & 166 & 171 & 188 \\
\hline $100 \% \mathrm{O}$ & 121 & 104 & 1.4 & 0 & 208 & 166 & 191 & 195 \\
\hline \multicolumn{9}{|l|}{ F Test } \\
\hline C & $219.2 * *$ & $25.6 * *$ & $178.6 * *$ & - & $60.7 * *$ & $4.0^{*}$ & $8.4^{* *}$ & $28.0 * *$ \\
\hline $\mathrm{CF}$ & $1.8^{\mathrm{ns}}$ & $0.7^{\mathrm{ns}}$ & $0.6^{\mathrm{ns}}$ & - & $3.5^{* *}$ & $0.9^{\mathrm{ns}}$ & $0.8^{\mathrm{ns}}$ & $1.5^{\mathrm{ns}}$ \\
\hline $\mathrm{C} \times \mathrm{CF}$ & $0.4^{\mathrm{ns}}$ & $0.5^{\mathrm{ns}}$ & $0.6^{\mathrm{ns}}$ & - & $3.4 * *$ & $1.9^{\mathrm{ns}}$ & $0.7^{\mathrm{ns}}$ & $0.5^{\mathrm{ns}}$ \\
\hline C.V. (\%) & 4.5 & 6.6 & 24.3 & - & 10.1 & 15.4 & 20.1 & 21.2 \\
\hline
\end{tabular}

(a) $\rightarrow$ Rainfall $\rightarrow$-Minimum Temperature $\rightarrow$ Maximum Temperature

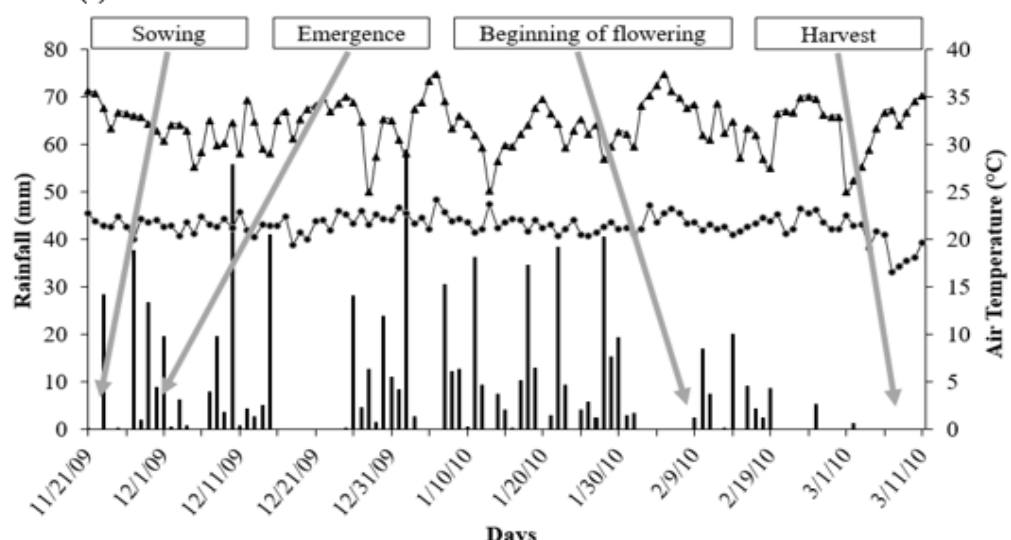

(b) Rainfall $\rightarrow$-Minimum Temperature $\rightarrow$ Maximum Temperature

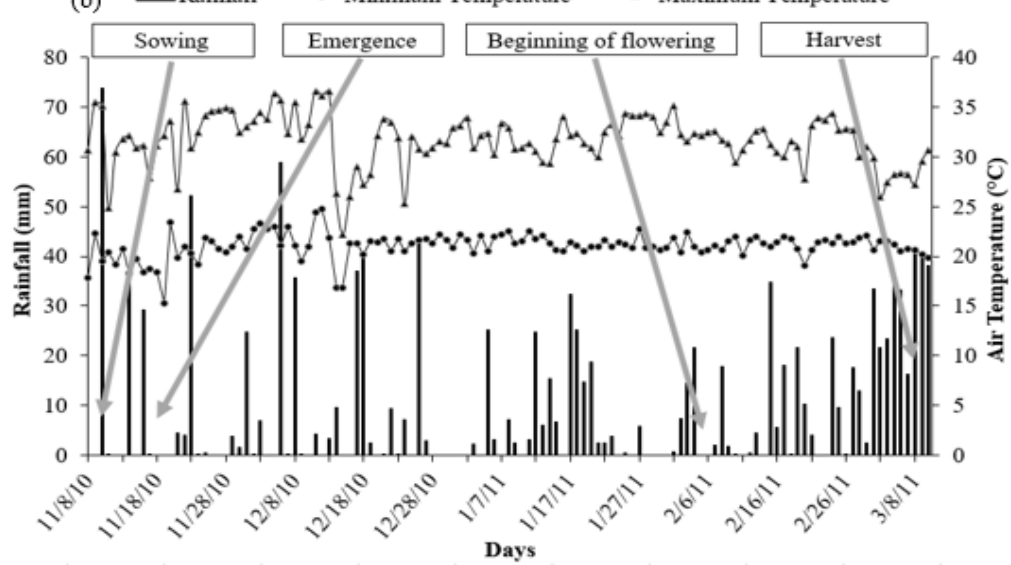

Fig 1. Daily values of rainfall $(\mathrm{mm})$, minimum and maximum temperature $(\stackrel{\circ}{-C})$ during development period of upland rice cultivars as function of mineral and organic fertilizer combinations, Selvíria - MS, 2009/10 (a) and 2010/11 (b). 
Table 2. Deployment of the interaction regarding the number of panicles per square meter of upland rice cultivars as function of combination of mineral and organic fertilizer, Selvíria (MS), 2009/10.

\begin{tabular}{|c|c|c|c|c|c|c|}
\hline \multicolumn{7}{|c|}{ Panicle per $\mathrm{m}^{-2}$} \\
\hline \multicolumn{7}{|c|}{ Combination of mineral and organic fertilizer } \\
\hline Cultivars & $100 \% \mathrm{M}$ & $\begin{array}{c}80 \% \mathrm{M}+ \\
20 \% \mathrm{O}\end{array}$ & $\begin{array}{c}60 \% \mathrm{M}+ \\
40 \% \mathrm{O}\end{array}$ & $\begin{array}{c}40 \% \mathrm{M}+ \\
60 \% \mathrm{O}\end{array}$ & $\begin{array}{c}20 \% \mathrm{M}+ \\
80 \% \mathrm{O}\end{array}$ & $100 \% 0$ \\
\hline Caiapó & $178 \mathrm{~B} \mathrm{~b}$ & $207 \mathrm{AB} b$ & $182 \mathrm{~B} \mathrm{~b}$ & $171 \mathrm{~B} \mathrm{~b}$ & $235 \mathrm{~A} \mathrm{a}$ & $212 \mathrm{AB}$ a \\
\hline Primavera & $180 \mathrm{~b}$ & $186 \mathrm{~b}$ & 197 b & 196 b & 187 b & 172 b \\
\hline IAC 202 & $231 \mathrm{~B} \mathrm{a}$ & $291 \mathrm{~A} a$ & $246 \mathrm{~B}$ a & $253 \mathrm{AB}$ a & $243 \mathrm{~B}$ a & $238 \mathrm{~B}$ a \\
\hline
\end{tabular}

Table 3. Average values of spikelets fertility, weight of 100 grains and productivity of grains obtained in upland rice cultivars as function of combinations of mineral and organic fertilizer, Selvíria (MS), 2009/10 and 2010/11.

\begin{tabular}{|c|c|c|c|c|c|c|c|}
\hline \multirow[t]{3}{*}{ Treatments } & \multicolumn{2}{|c|}{ Spikelets fertility } & \multicolumn{2}{|c|}{ Weight of 100 grains } & \multicolumn{3}{|c|}{ Productivity of grains } \\
\hline & \multicolumn{2}{|c|}{$\%$} & \multicolumn{2}{|c|}{ g } & \multicolumn{2}{|c|}{$\mathrm{kg} \mathrm{ha}^{-1}$} & \multirow[b]{2}{*}{ Average } \\
\hline & $09 / 10$ & $10 / 11$ & $09 / 10$ & $10 / 11$ & $09 / 10$ & $10 / 11$ & \\
\hline \multicolumn{8}{|l|}{ Cultivars (C) } \\
\hline Caiapó & 82.6 & $83.7 \mathrm{ab}$ & $2.5 \mathrm{~b}$ & $2.8 \mathrm{a}$ & $4,190 \mathrm{~b}$ & 3,013 a & $3,601 \mathrm{~b}$ \\
\hline Primavera & 79.3 & $80.5 \mathrm{~b}$ & $2.8 \mathrm{a}$ & $2.4 \mathrm{~b}$ & 4,976 a & $2,296 \mathrm{~b}$ & $3,636 \mathrm{~b}$ \\
\hline IAC 202 & 81.2 & 85.9 a & $2.2 \mathrm{~b}$ & $2.2 \mathrm{c}$ & 5,162 a & 3,310 a & 4,236 a \\
\hline \multicolumn{8}{|c|}{ Combination of mineral and organic fertilizer (CF) } \\
\hline $100 \% \mathrm{M}$ & 82.0 & 84.5 & 2.6 & 2.5 & $4,816 a b$ & 2,721 & 3,769 \\
\hline $80 \% \mathrm{M}+20 \% \mathrm{O}$ & 81.7 & 84.7 & 2.5 & 2.4 & $4,744 a b$ & 2,813 & 3,778 \\
\hline $60 \% M+40 \% O$ & 80.5 & 81.5 & 2.7 & 2.5 & $4,951 \mathrm{a}$ & 2,841 & 3,896 \\
\hline $40 \% M+60 \% O$ & 82.5 & 82.9 & 2.5 & 2.4 & $5,040 \mathrm{a}$ & 2,769 & 3,905 \\
\hline $20 \% \mathrm{M}+80 \% \mathrm{O}$ & 81.2 & 83.6 & 2.6 & 2.4 & $4,872 a b$ & 2,827 & 3,850 \\
\hline $100 \% 0$ & 78.3 & 83.1 & 2.3 & 2.4 & $4,233 \mathrm{~b}$ & 3,268 & 3,750 \\
\hline \multicolumn{8}{|l|}{ F Test } \\
\hline C & $1.60^{\mathrm{ns}}$ & $5.35 * *$ & $10.25^{* *}$ & $90.59 * *$ & $18.90^{* *}$ & $18.31 * *$ & $16.75^{* *}$ \\
\hline $\mathrm{CF}$ & $0.66^{\mathrm{ns}}$ & $0.48^{\mathrm{ns}}$ & $0.78^{\mathrm{ns}}$ & $0.68^{\mathrm{ns}}$ & $2.90^{*}$ & $1.32^{\mathrm{ns}}$ & $0.30^{\mathrm{ns}}$ \\
\hline $\mathrm{C} \times \mathrm{CF}$ & $0.48^{\mathrm{ns}}$ & $0.59^{\mathrm{ns}}$ & $1.27^{\mathrm{ns}}$ & $0.67^{\mathrm{ns}}$ & $1.25^{\mathrm{ns}}$ & $0.37^{\mathrm{ns}}$ & $0.74^{\mathrm{ns}}$ \\
\hline C.V. (\%) & 7.87 & 6.97 & 17.71 & 6.59 & 12.17 & 20.76 & 11.16 \\
\hline
\end{tabular}
Organic (0).

Table 4. Average values of yield of benefit, whole grains yield and broken grains obtained in upland rice cultivars as a function of combinations of mineral and organic fertilizer, Selvíria (MS), 2009/10 and 2010/11.

\begin{tabular}{|c|c|c|c|c|c|c|}
\hline \multirow{3}{*}{ Treatments } & \multicolumn{2}{|c|}{ Yield of benefit } & \multicolumn{2}{|c|}{ Whole grains yield } & \multicolumn{2}{|c|}{ Broken grains } \\
\hline & \multicolumn{2}{|c|}{$\%$} & \multicolumn{2}{|c|}{$\%$} & \multicolumn{2}{|c|}{$\%$} \\
\hline & $09 / 10$ & $10 / 11$ & $09 / 10$ & $10 / 11$ & $09 / 10$ & $10 / 11$ \\
\hline \multicolumn{7}{|l|}{ Cultivars (C) } \\
\hline Caiapó & 71.8 & $67.8 \mathrm{a}$ & $69.1 \mathrm{a}$ & $60.1 \mathrm{a}$ & $2.6 \mathrm{~b}$ & $6.9 \mathrm{~b}$ \\
\hline Primavera & 72.5 & $61.7 \mathrm{~b}$ & $67.7 \mathrm{ab}$ & $50.6 \mathrm{~b}$ & $4.7 \mathrm{a}$ & $10.8 \mathrm{a}$ \\
\hline IAC 202 & 71.7 & $62.9 \mathrm{~b}$ & $67.0 \mathrm{~b}$ & $52.8 \mathrm{~b}$ & $4.6 \mathrm{a}$ & $10.0 \mathrm{a}$ \\
\hline \multicolumn{7}{|c|}{ Combination of mineral and organic fertilizer (CF) } \\
\hline $100 \% \mathrm{M}$ & 72.0 & 65.3 & $68.1 \mathrm{ab}$ & 56.7 & 3.9 & 8.6 \\
\hline $80 \% M+20 \% O$ & 71.8 & 62.3 & $68.0 \mathrm{ab}$ & 52.6 & 3.8 & 9.6 \\
\hline $60 \% M+40 \% O$ & 72.2 & 64.4 & $68.1 \mathrm{ab}$ & 54.4 & 4.0 & 9.2 \\
\hline $40 \% M+60 \% O$ & 72.6 & 64.2 & $68.7 \mathrm{ab}$ & 53.2 & 3.9 & 9.4 \\
\hline $20 \% M+80 \% O$ & 72.6 & 63.5 & $68.8 \mathrm{a}$ & 53.3 & 3.8 & 10.1 \\
\hline $100 \% \mathrm{O}$ & 70.7 & 65.2 & $66.0 \mathrm{~b}$ & 56.7 & 4.6 & 8.5 \\
\hline \multicolumn{7}{|l|}{ F Test } \\
\hline $\mathrm{C}$ & $1.53^{\mathrm{ns}}$ & $36.53 * *$ & $5.64 * *$ & $30.20 * *$ & $41.99 * *$ & $40.35^{* *}$ \\
\hline $\mathrm{CF}$ & $2.05^{\mathrm{ns}}$ & $2.16^{\mathrm{ns}}$ & $2.29 *$ & $2.00^{\mathrm{ns}}$ & $1.49^{\mathrm{ns}}$ & $1.81^{\mathrm{ns}}$ \\
\hline $\mathrm{C} \times \mathrm{CF}$ & $1.11^{\mathrm{ns}}$ & $0.94^{\mathrm{ns}}$ & $0.90^{\mathrm{ns}}$ & $1.31^{\mathrm{ns}}$ & $0.85^{\mathrm{ns}}$ & $0.62^{\mathrm{ns}}$ \\
\hline C.V. (\%) & 2.44 & 4.12 & 3.36 & 8.12 & 22.19 & 17.33 \\
\hline
\end{tabular}

Average followed by distinct letter in the columns. differ by Tukey test at $5 \%$ of probability. ns - not significant ${ }^{*}$ and ${ }^{* *}$ significant at $5 \%$ and $1 \%$ de probability. respectively. Mineral (M) and Organic (0). 
Table 5. Soil chemical characteristics of the experimental area, evaluated in the 0.0 to 0.20 m depth, Selvíria - MS, $2009 / 10$.

\begin{tabular}{|c|c|c|c|c|c|c|c|c|c|c|}
\hline Year & $\begin{array}{l}\text { P resin } \\
\mathrm{mg} \mathrm{dm}^{-3}\end{array}$ & $\begin{array}{l}\text { O.M } \\
\mathrm{g} \mathrm{dm}^{-3}\end{array}$ & $\begin{array}{l}\mathrm{pH} \\
\mathrm{CaCl}_{2}\end{array}$ & K & $\mathrm{Ca}$ & $\begin{array}{l}\mathrm{Mg} \\
\mathrm{Ol}_{\mathrm{c}} \mathrm{dn}\end{array}$ & $\mathrm{H}+\mathrm{Al}$ & Al & CEC & $\begin{array}{l}\text { BS } \\
(\%)\end{array}$ \\
\hline 2009/10* & 17 & 13 & 5.2 & 2.9 & 33 & 14 & 27 & 0 & 77 & 65 \\
\hline
\end{tabular}

Table 6. Chemical composition, amounts of mineral and organic fertilizer, and amounts of $\mathrm{N}_{1} \mathrm{P}_{2} \mathrm{O}_{5}$ and $\mathrm{K}_{2} \mathrm{O}$ applied in the sowing of rice in each combination, Selvíria (MS), 2009/10 and 2010/11.

\begin{tabular}{|c|c|c|c|c|c|c|c|c|c|c|c|}
\hline \multirow{2}{*}{ Treatments } & \multicolumn{4}{|c|}{ Mineral } & \multicolumn{4}{|c|}{ Organic } & \multicolumn{3}{|c|}{ Total } \\
\hline & Amt & $\mathrm{N}$ & $\mathrm{P}_{2} \mathrm{O}_{5}$ & $\mathrm{~K}_{2} \mathrm{O}$ & Amt & $\mathrm{N}$ & $\mathrm{P}_{2} \mathrm{O}_{5}$ & $\mathrm{~K}_{2} \mathrm{O}$ & $\mathrm{N}^{1}$ & $\mathrm{P}_{2} \mathrm{O}_{5}$ & $\mathrm{~K}_{2} \mathrm{O}$ \\
\hline Composition & & $8 \%$ & $28 \%$ & $16 \%$ & & $1.18 \%$ & $2.20 \%$ & $0.80 \%$ & - & - & - \\
\hline & \multicolumn{11}{|c|}{$\mathrm{kg} \mathrm{ha}^{-1}$} \\
\hline \multicolumn{12}{|c|}{ Combination of mineral and organic fertilizer } \\
\hline $100 \% \mathrm{M}$ & 180 & 14 & 50 & 29 & 0 & 0 & 0 & 0 & 14 & 50 & 29 \\
\hline $80 \% M+20 \% 0$ & 144 & 11 & 40 & 23 & 240 & 3 & 5 & 2 & 14 & 45 & 25 \\
\hline $60 \% M+40 \% 0$ & 108 & 8 & 30 & 17 & 480 & 6 & 11 & 4 & 14 & 41 & 21 \\
\hline $40 \% M+60 \% O$ & 72 & 6 & 20 & 11 & 720 & 8 & 16 & 6 & 14 & 36 & 17 \\
\hline $20 \% M+80 \% O$ & 36 & 3 & 10 & 6 & 960 & 11 & 21 & 8 & 14 & 31 & 14 \\
\hline $100 \% 0$ & 0 & 0 & 0 & 0 & 1.200 & 14 & 26 & 10 & 14 & 26 & 10 \\
\hline
\end{tabular}

According to Fageria et al. (1982), fertilization and cultivar type are the main factors influencing number of panicles. The combination containing a high amount of mineral fertilizer provides a fast availability of the nutrient and may have favored the high number of panicles per $\mathrm{m}^{2}$ by the cultivar IAC 202 because this cultivar is modern. Also, according to Crusciol et al. (2012) and Pavinato et al. (2009), modern rice cultivars become more responsive by using fertilization. Boldieri et al. (2010) reported a high efficiency of nitrogen use by the cultivar IAC 202 compared to cultivars Caiapós and BRS Primavera.

We observed that, using most combinations of mineral and organic fertilizers, the cultivar IAC 202 presented the greatest potential for panicle production per $\mathrm{m}^{2}$, indicating that this cultivar has a high tillering capacity. Thus, the genetic factors of cultivars (traditional, Caiapó; intermediate, BRS Primavera; modern, IAC 202) influence tillering and, consequently, panicle production. According to Alvarez et al. (2012), traditional cultivars have a low tillering capacity, whereas modern cultivars have a high tillering potential. Moreover, according to Breseghello et al. (1998), intermediate cultivars have an average tillering potential. Gazotto (2011) also reported a high number of panicles per $\mathrm{m}^{2}$ for the cultivar IAC 202 (214) compared to Caiapó (183) and BRS Primavera (188). They did not report any changes after using combination of mineral and organic fertilizers under drought conditions.

In 2010/11, we verified that the cultivar IAC 202 presented a higher number of panicles per $\mathrm{m}^{2}$ than the cultivar Caiapó, confirming that this is a characteristic of that cultivar. Modern cultivars such as IAC 202 have high tillering potential compared to traditional cultivars such as Caiapó (Breseghello et al., 1998, Pavinato et al., 2009). Plants with high number of tillers provide more panicles per $\mathrm{m}^{2}$. Arf et al. (2000), studied sowing time of upland rice cultivars during two cultivation years and observed that the cultivar IAC 202 had the highest number of panicles per $\mathrm{m}^{2}$ compared to cultivar Caiapó regarding the average values for growing seasons related to the first cultivation year.
The results for number of spikelets per panicle showed that (Table 1) cultivar Caiapó has $18 \%$ and $19 \%$ less spikelets (164) than the cultivars BRS Primavera (200) and IAC 202 (203), respectively, during the $2009 / 10$ crop. During 2010/11, the number of spikelets of the cultivar IAC 202 (228) was 32\% higher than the cultivar BRS Primavera (173) and $56 \%$ higher than the cultivar Caiapó (146). Production of spikelets per panicle is a characteristic associated with genetic factors, indicating a high production of spikelets per panicle by the cultivar IAC 202, a low production for the cultivar Caiapó and an average production for the cultivar BRS Primavera. According to Fageria (1989), one of the factors that influence the number of spikelets per panicle is the cultivar itself. Arf et al. (2012), studied upland rice cultivars in the same region as of this study and verified that the cultivar IAC 202 had a great number of spikelets per panicle, resulting in $19 \%$ higher spikelets than the cultivar BRS Primavera and $27 \%$ higher than the cultivar Caiapó. Boldieri et al. (2010) observed that the cultivar IAC 202 has $22 \%$ and $35 \%$ higher number of spikelets per panicle compared to the cultivars BRS Primavera and Caiapó, respectively. Soratto et al. (2010) also observed a superiority in the number of spikelets per panicle in cultivar IAC 202 (118), surpassing $49 \%$ the cultivar Caiapó (79).

\section{Spikelets fertility, weight of 100 grains and productivity of grains}

The fertility of spikelets (Table 3 ) during 2009/10 showed no differences between cultivars and combinations of mineral and organic fertilizers. In 2010/11, the cultivar IAC 202 presented a fertility value higher than the cultivar BRS Primavera. The fertility of spikelets is the ratio between full spikelets and total spikelets (Buzetti et al., 2006; Fageria, 1989). The greater spikelet fertility cause greater number of full spikelets in the panicle. According to Hernandes et al. (2010) and Buzetti et al. (2006), the number of full spikelets depends on carbohydrate translocation. Hernandes et al. (2010) reported that such translocation is influenced by genetic factors. Thus, the fertility of spikelets depends on the genotype (Fageria et al., 2007). 
Regarding 100 grain mass (Table 3), the cultivar BRS Primavera presented an average higher than the cultivars Caiapó and IAC 202 during 2009/10. However, the cultivar Caiapó presented the highest average in 2010/11. The BRS Primavera presented an intermediate value and the IAC 202 presented the lowest 100 grains mass. In both years, there were no changes in 100 grains mass using mineral and organic fertilizer combinations.

Grain mass is a stable varietal characteristic that depends on the size of the bark. Therefore, the grain cannot be more than the bark regardless of climatic conditions and the nutrient supplies (Yoshida, 1981). In specific cases, the excess of rainfalls after the grain maturation stage may lead to a decrease in mass. During the 2010/11 harvest, there was an excess of rainfalls (Fig $1 \mathrm{~b}$ ). This caused a delay in the harvest and also germination of BRS Primavera grains on panicles. The seed germination process in the mother plant is called viviparity (Taiz and Zeiger, 2013; Cardoso, 2004; Barbedo and Marcos Filho, 1998) and is a varietal characteristic favored by a humid climate (Taiz and Zeiger, 2013). In the germination process there is a degradation of reserve substances aiming the production of energy for seedling growth. Such process may have influenced the loss of grain mass of the cultivar BRS Primavera when comparing both cultivation years, causing translocation of substances to the seedling.

Baek and Chung (2014), studied two rice cultivars (Hopum and Shindongjin) subjected to five periods of artificial rainfalls $(0,3,5,7$ and 10 days) at two plant stages ( 5 days and 15 days before harvest) and reported that there was an increase in the percentage of germination of pre-harvest rice grains according to the increase in days of rainfalls $(0 \%$, $1.8 \%, 7.0 \%, 15.0 \%$ and $15.8 \%$ of the grains) for the cultivar Hopum, 15 days before harvest. Five days before harvest, the same cultivar presented a high germination of upper grains during pre-harvest according to the increase in days with rainfalls $(0 \%, 6.3 \%, 7.3 \%, 15.3 \%$ and $25.8 \%$ of the germinated grains for $0,3,5,7$ and 10 days of rainfall, respectively). The cultivar Shindongjin did not show differences.

Studying traditional (Caiapó) and modern (Maravilha) cultivars, Alvarez et al. (2012) observed that the 1,000 grains mass was higher for the cultivar Caiapó than for the cultivar Maravilha. According to the authors, this result is attributed to the type of grain of the cultivars. The cultivar Caiapó has long grains and the cultivar Maravilha has long-fine grains. Soratto et al. (2010) reported a greater 1,000 grains mass for the cultivar Caiapó than for the cultivar IAC 202. Gazotto (2011) reported a high grain mass for the cultivar Caiapó compared to the cultivar BRS Primavera. During a two years experiment, Boldieri et al. (2010), and Arf et al. (2012) observed a higher 100 grains mass for the cultivar Caiapó, followed by the cultivars BRS Primavera and IAC 202, which had a lower 100 grains mass.

Regarding grain yield in the 2009/10 crop, the cultivar IAC 202 yielded 5,162 kg ha- ${ }^{-1}$ and the BRS Primavera yielded $4,976 \mathrm{~kg} \mathrm{ha}^{-1}$, both higher than the cultivar Caiapó which yielded only 4,190 $\mathrm{kg} \mathrm{ha}^{-1}$. Observing the Table 1 , it can be seen that the cultivar Caiapó had a high plant height, and consequently a high lodging. This characteristic is attributed to traditional plants (Caiapó). Due to plant lodging, there are grain losses at the time of harvest, culminating in a low grain yield. According to the average of the two years study, there was superiority for the cultivar IAC 202 over cultivars Caiapó and BRS Primavera. This shows that cultivar IAC 202 was more stable under different climatic conditions.

Gazotto (2011) observed a 32\% higher yield for the cultivar IAC 202 over Caiapó, which may also be related to grain loss caused by lodging of Caiapó cultivar. Nascente et al. (2013), studied upland rice using a no-tillage system and found that the productivity of the cultivar BRS Primavera exceeded the productivity of the cultivar Caiapó by $16 \%$. Although the authors did not evaluate plant lodging, this could have been the probable cause for the low grain yield observed for the Caiapó cultivar, which was $7 \mathrm{~cm}$ taller than the cultivar BRS Primavera. According to Alves et al. (2015), growth regulator studies are conducted on rice cultivation aiming to decrease plant height, and consequently lodging, obtaining a better use of grain yield.

In 2010/11, the cultivar IAC 202 had the highest grain yield $\left(3,310 \mathrm{~kg} \mathrm{ha}^{-1}\right)$, but was similar to the cultivar Caiapó $(3,013$ $\left.\mathrm{kg} \mathrm{ha}^{-1}\right)$. Both cultivars presented productivity higher than the cultivar BRS Primavera $\left(2,296 \mathrm{~kg} \mathrm{ha}^{-1}\right)$. The viviparity of the cultivar BRS Primavera provided a $17 \%$ decrease in 100 grains mass, comparing 2009/10 with 2010/11. This affected the grain yield, allowing the cultivars Caiapó and IAC 202 to present $31 \%$ and $44 \%$ more productivity, respectively.

Boldieri et al. (2010) and Arf et al. (2012) also reported higher grain yield for cultivar IAC 202 than the cultivar BRS Primavera. For Arf et al. (2012), this can be attributed to the lodging of plants of the cultivar BRS Primavera, which caused grain losses at the time of harvest. Fidelis et al. (2013), studied upland rice cultivars in function of two levels of fertilization with phosphorus (low and high) and reported that, on average, the cultivar Caiapó had a grain yield 38\% higher than the cultivar BRS Primavera. Arf et al. (2000), studied sowing times and upland rice cultivars and observed that the grain yield of the cultivars Caiapó and BRS Primavera were similar for both cultivation years.

In relation to mineral and organic fertilizer combinations during $2009 / 10$, the combinations of $60 \%$ mineral $+40 \%$ organic and $40 \%$ mineral $+60 \%$ organic resulted in an increase of $17 \%$ and $19 \%$ in productivity, respectively, values higher than application of $100 \%$ organic fertilization. The spikelet fertility was $2.8 \%$ and $5.4 \%$ higher by combination of $60 \%$ mineral $+40 \%$ organic and $40 \%$ mineral $+60 \%$ organic, respectively, compared to $100 \%$ organic fertilizer. These treatments also increased the 100 grains mass by $17.4 \%$ and $8.7 \%$, respectively. Thus, intermediate combinations of mineral and organic fertilizers promoted an increase in spikelet fertility and 100 grains mass compared to $100 \%$ organic fertilizer, culminating in a high grain yield.

Possibly, the use of mineral and organic fertilizers at the combinations of $60 \%+40 \%$ and $40 \%+60 \%$ provided nutrients for rice plants in a balanced way (Table 6). While the mineral fertilizer presents a fast nutrient availability for crops, the organic fertilizer becomes available in a slower way (Raij et al., 1997; Magro et al., 2010; Quadros et al., 2012) because it depends on the mineralization of the organic matter. Thus, intermediate combinations of mineral and organic fertilizers provided a better use of nutrients on irrigated upland rice cultivation.

There was a decrease in productivity from one agricultural year to another. A possible explanation would be the intense rainfalls that occurred soon after sowing and the intense rainfalls during the harvesting phase. After sowing, there 
was sedimentation of the sowing furrow and an uneven germination of seedlings, leading to problems. During the maturation and harvesting phases, there was a delay in harvest leading to the beginning of panicle germination, $a$ fact observed for the cultivar BRS Primavera.

\section{Grain quality: Yield of benefit, whole grains yield and} broken grains

Regarding the yield of benefit (Table 4), the cultivars and the fertilization did not present differences in 2009/10. In 2010/11, the Caiapó cultivar (67.8\%) stood out, differing from the cultivars IAC 202 and BRS Primavera (62.9\% and $61.7 \%$, respectively). According to Embrapa (1992), the yield of benefit (intact plus broken grains) varied according to cultivar, moisture content, grain shape and size, harvesting and drying methods, and climatic conditions after flowering. Gazotto (2011), studied the same cultivars and the same combinations of mineral and organic fertilizers on unirrigated rice and reported that the cultivars Caiapó and IAC 202 have values for yield of benefit (61.7\% and 61.9\%, respectively) higher than the cultivar BRS Primavera (58.3\%). Regarding the whole grains yield (Table 4), the cultivar Caiapó had the highest average (69.1\%) in 2009/10, differing from the cultivar IAC 202 (67.0\%). In 2010/11, the cultivar Caiapó had a higher average $(60.1 \%)$ than the cultivars BRS Primavera (50.6\%) and IAC 202 (52.8\%). It can be inferred that whole grain yield varies according to genotype. The cultivar Caiapó always stood out and presented the highest values. Arf et al. (2000), studied six sowing times and nine cultivars and observed a whole grains yield for the cultivar Caiapó higher than the cultivar IAC 202 during two consecutive cultivation years. Soares et al. (2003) observed similar values for yield of benefit $(70 \%)$ for the cultivars Caiapó, BRS Primavera and IAC 202. However, the authors verified that the whole grains yield was higher for the cultivar Caiapó (62\%), average for the cultivar IAC 202 (57\%) and low for the cultivar BRS Primavera (44\%). Ribeiro et al. (2004) reported a high grain yield for the cultivar Caiapó (64\%), an intermediate value for the cultivar BRS Primavera (61\%) and a low value for the cultivar IAC 202 (53\%).

In 2009/10, it was verified that the whole grain yield was higher under the combination of $20 \%$ mineral $+80 \%$ organic fertilizers and lower applying $100 \%$ organic fertilizer. There was low spikelet fertility (Table 3 ) and a low yield of benefit using $100 \%$ organic fertilizer. This result indicates that amount of straw was higher than other treatments. It resulted in a decrease in whole grain yield, using $100 \%$ organic fertilizer. According to Freitas et al. (2007), whole grain yield correlates positively with fertility of spikelets, by interfering one variable that influences the others.

In both of two cultivation years, the treatments presented an excellent quality of grains, with a whole grains yield higher than $50 \%$, that is higher than that required for the commercialization of the product at a national level, where values for whole grains yields higher than $40 \%$ or more are considered adequate (Fornasieri Filho and Fornasieri, 2006; Vieira and Carvalho, 1999).

Regarding broken grains (Table 4), the cultivar Caiapó had the lowest value in both cultivation years, differing from the other cultivars. It should be emphasized that the superiority in yield of benefit and whole grains yield and the lowest percentage of broken grains of the cultivar Caiapó all indicate a high industrial quality. According to Morais et al. (2006) and Soares et al. (1993), the grains of the cultivar Caiapó had an excellent acceptance in the market due to a high whole grains yield and a good culinary quality. Soares et al. (2003), studied twenty upland rice samples (cultivars and lineages) and verified the superior industrial grain quality of Caiapó cultivar. They reported a low percentage of broken grains for this cultivar during two years of study.

In general, comparison of the years 2009/10 and 2010/11 shows a decrease in the yield of benefit and in whole grains yield and an increase in broken grains. As already mentioned, there was an excess of rainfalls at the time of harvest, causing a delay in harvesting procedure. The whole grain yield is an important parameter for the determination of the commercial value of rice, by which the yield of benefit are negatively influenced by the moisture of grains at harvest (Vieira and Rabelo, 2006; Fornasieri Filho and Fornasieri, 2006; Marchezan, 1991). The late harvesting of rice decreases the whole grain yield by increasing grain exposure to climatic conditions (Binotti et al., 2007) such as rainfalls. Thus, excessive grain moisture at this stage may have caused cracks. At the time of determination of yield the cracks may have caused a low whole grains yield and a high amount of broken grains. According to Fornasieri Filho and Fornasieri (2006), the alternative drying and wetting process results in internal grain crushing and mechanical injuries during the threshing phase, resulting in a decrease in whole grains yield.

\section{Materials and Methods}

\section{Description of the area: location, soil and climate}

We conducted the experiment during the years of 2009/10 and 2010/11 at an experimental area of the Faculty of Engineering, UNESP, Ilha Solteira campus, located in the municipality of Selvíria, MS, approximately at 5122' W and $20 \div 22$ ' $S$ at an altitude of 335 meters. The soil of the experimental area, according to Santos et al. (2013), is a typical clayey dystroferric Red Latosol. The chemical attributes of the soil, at the $0-20 \mathrm{~cm}$ layer, are shown in Table 5.

The average annual rainfall is $1,330 \mathrm{~mm}$. The average minimum temperature is $19^{\circ} \mathrm{C}$ and the average maximum temperature is $31^{\circ} \mathrm{C}$ (Portugal et al., 2015). The mean relative air humidity is $66 \%$. During the experimental period, climatic data for rainfalls $(\mathrm{mm})$ and maximum and minimum temperatures were collected. They are shown in Fig 1 ( $a$ and b).

The soil preparation was carried out using a scarifier and two harrows for soil disintegration and leveling. The latter was performed on the eve of sowing.

\section{Experimental design and treatments}

The experimental design was randomized blocks in a $3 \times 6$ factorial design with four replications. The plots consisted of five rows each five meters long, spaced $0.35 \mathrm{~m}$ apart. The measurement area was the three main rows, ignoring 0.50 $\mathrm{m}$ at both ends.

The treatments consisted of three different types of rice cultivars (Caiapó, traditional type; Primavera, intermediate type; and IAC 202, modern type) and six combinations of 
mineral and organic fertilizers (100\% mineral fertilizer, $80 \%$ mineral fertilizer $+20 \%$ organic fertilizer, $60 \%$ mineral fertilizer $+40 \%$ organic fertilizer, $40 \%$ mineral fertilizer + $60 \%$ organic fertilizer, $20 \%$ mineral fertilizer $+80 \%$ organic fertilizer and $100 \%$ organic fertilizer).

\section{Plant materials}

We used the cultivars Caiapó, BRS Primavera and IAC 202, which are traditional, intermediate and modern types, respectively. The cultivar Caiapó had a medium size (110-130 $\mathrm{cm}$ ), a medium cycle (128 days), a period between emergence and flowering of 95-100 days, long grains, and is moderately susceptible to plant lodging (Soares et al., 1993). The cultivar BRS Primavera had a medium size (100-120 cm), a short cycle (112 days), a period between emergence and flowering of 80 days, long and fine grains (needles), and is moderately susceptible to lodging (Breseghello et al., 1998). The cultivar IAC 202 had a low size $(87 \mathrm{~cm})$, a short cycle (120 days), a period between emergence and flowering of 87 days, long and fine grains and is resistant to lodging (Bastos, 2000).

\section{Fertilizers}

The volume of sowing fertilizer, for the two years, was 180 $\mathrm{kg} \mathrm{ha}^{-1}$ using the formulation 08-28-16 (mineral fertilizer). The volume of organic fertilizer based on slaughterhouse waste was $1.2 \mathrm{t} \mathrm{ha}^{-1}$ (organic fertilizer), whose analysis shows approximately $35 \%$ of organic matter, $2.20 \%$ of phosphorus $\left(\mathrm{P}_{2} \mathrm{O}_{5}\right), 1.18 \%$ of nitrogen $(\mathrm{N}), 0.80 \%$ of potassium $\left(\mathrm{K}_{2} \mathrm{O}\right)$ and a carbon/nitrogen ratio equal to $11 / 1$. We determined mineral and organic fertilizer combinations based on the nitrogen supply. All treatments had the same dose of $\mathrm{N}$. The amounts of nutrients used, according to each treatment (combinations), are shown in Table 6.

The organic fertilizer presented a granule shape, similar to the mineral fertilizer. It is also easy to handle. It is a product coming from agroindustrial residues, such as: slaughterhouse (bone meal, blood meal, sludge from decantation in anaerobic lagoons and ruminated bolus) of cattle, poultry and swine, besides manure from feedlots and byproducts of sugar/ethanol factory produced by Olganossolvi ${ }^{\oplus}$ company, located in Coroados, São Paulo state in Brazil (Nakao et al., 2016)

\section{Installation and conducting of field experiment}

The experimental area was grooved at a spacing of $0.35 \mathrm{~m}$. Soon after, the fertilization was performed using different mineral and organic fertilizer combinations. The sowing was performed mechanically on $11 / 21 / 2009$ and on $11 / 08 / 2010$. According to Arf et al. (2000), this month was the most suitable for sowing irrigated rice by spraying in the region. It resulted in high productivity. The seeds were treated with imidacloprid and thiodicarb at doses of $120 \mathrm{~g}$ a.i. and $360 \mathrm{~g}$ a.i. per $100 \mathrm{~kg}$ of seeds in both years, respectively.

Soon after sowing, the herbicide pendimethalin $\left(1,400 \mathrm{~g} \mathrm{ha}^{-1}\right.$ of a.i.) were applied at pre-emergence using a traction sprayer with a flow rate of $200 \mathrm{~L} \mathrm{ha}^{-1}$ in both cultivation years. During the first cultivation year, herbicide bentazon (720 $\mathrm{g} \mathrm{ha}^{-1}$ a.i.) was applied as post-emergence at 18 days after emergence (DAE). A second post-emergence application was performed using the 2,4-D herbicide $(1,005$ $\mathrm{g} \mathrm{ha}^{-1}$ a.i.) at 39 DAE. In both post-emergence applications, a manual backpack sprayer was used with a flow rate of approximately $160 \mathrm{~L} \mathrm{ha}^{-1}$. During the second year, the weeds were not controlled by the pre-emergence herbicide but controlled manually using weeding a hoe.

Cover fertilization was made at 32 and 35 DAE for the first and the second cultivation years, respectively, using $70 \mathrm{~kg}$ $\mathrm{ha}^{-1}$ of $\mathrm{N}$ as ammonium sulfate, applying a water blade of approximately $10 \mathrm{~mm}$ for the incorporation of the fertilizer. Irrigationwas performed using a fixed sprinkler irrigation system with a mean water volume of $3.3 \mathrm{~mm} \mathrm{hour}{ }^{-1}$, whenever necessary. Three crop coefficients (Kc) were considered for water management. The water management was distributed over four periods between emergence and harvest. For the vegetative phase, the value of 0.4 was used. Two crop coefficients $(\mathrm{Kc})$ were used for the reproductive phase, an initial of 0.70 and a final of 1.00. For the maturation phase, these values were inverted, by which the initial was 1.00 and the final was 0.70 . Rainfall was collected in a Ville de Paris rain gauge installed at the Experimental Farm.

\section{Variables analyzed}

We evaluated the average height of 10 random plants in the useful area of each plot by measuring the distance from the soil surface to the upper end of the highest panicle. We evaluated the lodging of plants by observation during the maturation phase using the following score: $0=$ without lodging, $1=$ up to $5 \%, 2=5-25 \%, 3=25-50 \%$, $4=50-75 \%$ and $5=75-100 \%$ of lodged plants. We evaluated the number of panicles per $\mathrm{m}^{2}$ by counting the number of panicles in $1.0 \mathrm{~m}$ row of plants within the useful area of the plots, and subsequently we calculated such value per square meter. We obtained the number of spikelets per panicle by counting the number of grains of 20 panicles collected at the time of harvest in each plot. The fertility of spikelets was calculated based on the percentage of unfilled spikelets compared to the total number of spikelets. The 100 grains mass was evaluated by random sampling and by weighing two samples of 100 grains from each plot (13\% wet basis). The grain yield was evaluated by weighing grains with husks collected from the useful area of the plots, correcting humidity to $13 \%$ and converting the results into $\mathrm{kg} \mathrm{ha}^{-1}$. The yield of benefit was evaluated using one sample of $100 \mathrm{~g}$ of rice grains with husks from each plot. The sample was processed in test equipment for 1 minute. Then, the polished grains were weighed and the resulting value was considered as the yield of benefit. The results were expressed as percentage. Later, the polished grains were placed in a "Trieur" $\mathrm{n}$ - 2 and grain separation was performed for 30 seconds. The grains that remained in the "Trieur" were weighed, obtaining the yield of intact grains and broken grains, both expressed as percentage.

\section{Statistical analysis}

Data were subjected to analysis of variance by $F$ test ( $p \leq 0.01$ and $\leq 0.05$ ) and means were compared by Tukey test $(p \leq 0.05)$. The statistical software Sisvar was used for analyses (Ferreira, 2011). 


\section{Conclusion}

The cultivar IAC 202 presents a productive potential greater than the cultivars Caiapó and BRS Primavera. The combination of $60 \%$ mineral $+40 \%$ organic and $40 \%$ mineral $+60 \%$ organic fertilizers resulted in a grain yield greater than the that of $100 \%$ organic fertilizer. The cultivar Caiapó stood out by presenting the highest grain quality. The organic fertilizer based on slaughterhouse waste can be used for upland rice cultivation.

\section{Acknowledgements}

The authors would like to thank the Foundation Research Support of the State of São Paulo (FAPESP) for the scholarship awarded to the first author (Process FAPESP $\mathrm{n}$. 2009/14627-0) and for funding current research.

\section{References}

Alvarez RCF, Crusciol CAC, Nascente AS (2012) Análise de crescimento e produtividade de cultivares de arroz de terras altas dos tipos tradicional, intermediário e moderno. Pesq Agrop Trop. 42: 397-406.

Alves CJ, Arf O, Garcia NFS, Galindo FS, Galassi AD (2015) Thiadizuron aumenta a produtividade em arroz de terras altas. Pesq Agrop Trop. 45: 333-339.

Arf O, Bastos JCHAG, Silva MG, Sá ME, Rodrigues RAF, Buzetti S (2005) Manejo do solo e épocas de aplicação de nitrogênio na produção de arroz de terras altas. Acta Sci Biol Sci. 27: 215-223.

Arf O, Nascimento V, Rodrigues RAF, Alvarez RCF, Gitti DC, Sá ME (2012) Uso de etil-trinexapac em cultivares de arroz de terras altas. Pesq Agrop Trop. 42: 150-158.

Arf O, Rodrigues RAF, Nascente AS, Lacerda MC (2015) Espaçamento e adubação nitrogenada afetando o desenvolvimento do arroz de terras altas sob plantio direto. Rev Ceres. 62: 475-482.

Arf O, Rodrigues RAF, Sá ME, Crusciol CAC (2000) Influência da época de semeadura no comportamento de cultivares de arroz irrigado por aspersão em Selvíria, MS. Pesq Agrop Bras. 35: 1967-1976.

Artigiani ACCA, Crusciol CAC, Arf O, Alvarez RCF, Nascente AS (2012) Produtividade e qualidade industrial do arroz de terras altas em função da disponibilidade hídrica e adubação. Pesq Agrop Trop. 42: 340-349.

Baek JS, Chung NJ (2014) Influence of rainfall during the ripening stage on pre-harvest sprouting, seed quality, and longevity of rice (Oryza sativa L.). Korean J Crop Sci. 59: 406-412.

Barbedo CJ, Marcos Filho J (1998) Tolerância à dessecação em sementes. Acta Bot Bras. 12: 145-164.

Barbosa Filho MP, Fageria NK, Santos DF, Couto PA (2006) Aplicação de rochas silicáticas como fontes alternativas de potássio para a acultura do arroz de terras altas. Esp Geogr. 9: 63-84.

Bastos CR (2000) IAC 202: Arroz de alta produtividade e qualidade para cultura de sequeiro. O Agronômico. 52: 2425.

Binotti FFS, Arf O, Fernandes FA, Sá ME (2007) Momento de colheita e períodos de armazenamento no rendimento industrial e na qualidade fisiológica do arroz de terras altas. Acta Sci Agron. 29: 219-226.
Boldieri FM, Cazetta DA, Fornasieri Filho D (2010) Adubação nitrogenada em cultivares de arroz de terras altas. Rev Ceres. 57: 421-428.

Breseghello F, Castro EM, Morais OP (1998) Cultivares de arroz. In: Breseghello F, Stone LF (ed) Tecnologia para arroz de terras altas. Embrapa Arroz e Feijão, Santo Antônio de Goiás. p.41-53.

Buzetti S, Bazanini GC, Freitas JG, Andreotti M, Arf O, Sá ME, Meira FA (2006) Resposta de cultivares de arroz a doses de nitrogênio e do regulados de crescimento cloreto de clormequat. Pesq Agrop Bras. 41: 1731-1737.

Cardoso VJM (2004) Germinação. In: Kerbauy GG (ed) Fisiologia Vegetal. Guanabara Koogan, Rio de Janeiro. p.386- 408 .

Cazetta DA, Arf O, Buzetti S, Sá ME, Rodrigues RAF (2008) Desempenho do arroz de terras altas com a aplicação de doses de nitrogênio e em sucessão às culturas de cobertura do solo em sistema de plantio direto. Bragantia. 67: 471-479.

Che SG, Zhao BQ, Li YT, Yuan L, Lin ZA, Hu SW, Shen B (2016) Nutrient uptake requirements with increasing grain yield for rice in China. J Integr Agric. 15: 907-917.

Colombari Filho JM, Rangel PHN (2015) Cultivares. In: Borém A, Rangel PHN (ed) Arroz do plantio à colheita. UFV, Viçosa. p.84-121.

Crusciol CAC, Arf O, Soratto RP, Machado RM (2003) Qualidade industrial e teores de nutrientes dos grãos do arroz de terras altas sob diferentes lâminas de água e níveis de adubação mineral. Acta Sci Agron. 25: 409-415.

Crusciol CAC, Fernandes AM, Carmeis Filho ACA, Alvarez RCF (2016) Macronutrient uptake and removal by upland rice cultivars with different plant architecture. ver Bras Cienc Solo. 40: 1-20.

Crusciol CAC, Mancuso MAC, Garcia RA, Castro GSA (2012) Crescimento radicular e aéreo de cultivares de arroz de terras altas em função da calagem. Bragantia. 71: 256-263.

Dias AFS, Silva FN, Maia SSS (2010) Resposta do arroz de sequeiro à adubação com NPK em solos do município de JiParaná/Rondônia. Rev Verde Agroecol Desenv Sust. 5: 120124.

Empresa Brasileira de Pesquisa Agropecuária - Embrapa (1992) Serviço de Produção de Informação. Recomendações técnicas para arroz irrigado no CentroOeste, Norte e Nordeste. Embrapa, Brasília. 140 p.

Fageria NK (1989) Solos tropicais e aspectos fisiológicos das culturas. EMBRAPA-DPU, Brasília. p. 425.

Fageria NK (2000) Eficiência do uso de potássio pelos genótipos de arroz de terras altas. Pesq Agrop Bras. 35 2115-2120.

Fageria NK, Barbosa Filho MP, Garber MJ (1982) Nível de nutriente e densidade de plantio adequados para experimentos com arroz em casa de vegetação. Pesq Agrop Bras. 17: 1279-1284.

Fageria NK, Santos AB, Cutrim VA (2007) Produtividade de arroz irrigado e eficiência de uso do nitrogênio influenciadas pela fertilização nitrogenada. Pesq Agrop Bras. 42: 1029-1034.

Ferreira CM, Santiago CM (2012) Informações técnicas sobre o arroz de terras altas: estados de Mato Grosso e Rondônia - safras 2010/2011 e 2011/2012. Embrapa Arroz e Feijão, Santo Antônio de Goiás. 112 p.

Ferreira DF (2011) SISVAR: a computer statistical analysis system. Ciênc Agrotec. 35:1039-1042. 
Fidelis RR, Pinto LC, Santos MM, Faccirolli AM, Brandão DR, Scheidt G (2013) Efeito do fósforo em genótipos de arroz em solos de Cerrado. Científica. 41: 46-51.

Food and Agriculture Organization of the United Nations (FAO). 2012. Available at Web site http://www.fao.org/faostat/en/\#data/QL (verified 06 April 2017).

Fornasieri Filho D, Fornasieri JL (2006) Manual da cultura do arroz. FUNEP, Jaboticabal. $589 \mathrm{p}$.

Freitas JG, Cantarella H, Salomon MV, Malavolta VMA, Castro LHSM, Gallo PB, Azzini LE (2007) Produtividade de cultivares de arroz irrigado resultante da aplicação de doses de nitrogênio. Bragantia. 66: 317-325.

Garcia RA, Gazola E, Merlin A, Villas Bôas RL, Crusciol CAC (2009) Crescimento aéreo e radicular de arroz de terras altas em função da adubação fosfatada e bioestimulante. Biosci J. 25: 65-72.

Gazotto AS (2011) Adubação mineral e orgânica em cultivares de arroz de terras altas. Trabalho de conclusão de curso. Ilha Solteira, SP: Universidade Estadual Paulista "Júlio de Mesquita Filho", Faculdade de Engenharia, Ilha Solteira, SP.

Gitti DC, Arf O, Portugal JR, Corsini DCDC, Rodrigues RAF, Kaneko FH (2012) Coberturas vegetais, doses de nitrogênio e inoculação de sementes com Azospirillum brasilense em arroz de terras altas no sistema plantio direto. Bragantia. 71: 509-517.

Global Rice Science Partnership - GRiSP. 2013. Rice almanac, 4. ed. International Rice Research Institute, Los Baños (Philippines). $283 \mathrm{p}$.

Guimarães CM, Stone LS (2004) Arroz de terras altas em rotação com soja. Pesq Agrop Trop. 34: 127-132.

Hernandes A, Buzetti S, Andreotti M, Arf O, Sá ME (2010) Doses, Fontes e épocas de aplicação de nitrogênio em cultivares de arroz. Ciênc Agrotec. 34: 307-312.

Imade AR, Thanki JD, Gudadhe NN (2015) Integrated effect of organic manures and inorganic fertilizers on productivity, NPK uptake and profitability of transplanted rice. Res Crops. 16: 401-405.

Instituto Brasileiro de Geografia e Estatística - IBGE (2012) Available at Web site https://sidra.ibge.gov.br/tabela/1092\#resultado (verified 06 April 2017).

Magro FO, Arruda N, Casa J, Salata AC, Cardoso All, Fernandes DM (2010) Composto orgânico na produção e qualidade de sementes de brócolis. Ciênc Agrotec. 34: 596602.

Marchezan E (1991) Época de semeadura e rendimento industrial em grãos inteiros de cultivares de arroz (Oryza sativa L.). tese. Piracicaba, SP: Escola Superior de Agricultura "Luiz de Queiroz", Universidade de São Paulo, Piracicaba, SP.

Mohanty S (2013) Trends in global rice consumption. Rice Today. 12: 44-45.

Morais OP, Rangel PHN, Fagundes PRR, Castro EM, Neves PCF, Cutrim VA, Prabhu AS, Brondani $C$, Magalhães Júnior AM (2006) Melhoramento Genético. In: Santos B, Stone LF, Vieira NRA (eds) A cultura do arroz no Brasil, 2nd edn. Embrapa Arroz e Feijão, Santo Antônio de Goiás. p. 289358.

Morais OP, Sant'Ana EP, Chatel M, Prabhu AS, Castro EM (1983) Melhoramento genético voltado para a cultura do arroz de sequeiro. In: Ferreira ME, Yamada T, Malavolta E (ed) Cultura do arroz de sequeiro. Instituto Internacional da Potassa, Piracicaba, p. 145-178.

Moura Neto FP, Soares AA, Aidar H (2002) Desempenho de cultivares de arroz de terras altas sob plantio direto e convencional. Ciênc Agrotec. 26: 904-910.

Nakao AH, Rodrigues RAF, Souza MFP, Dickmann L, Catalani GC, Centeno DC (2016) Aplicação de composto orgânico e adubo químico no feijoeiro e seu efeito residual sobre a cultura do milho. Cult Agron. 25: 387-400.

Nascente AS, Oliveira P, Kluthcouski J, Freitas RJ, Favarin JL (2013) Cultivares de arroz de terras altas afetadas pelo manejo do solo. Rev Bras Ciênc Agrá. 8: 428-434.

Nunes WACA, Menezes JFS, Benites VM, Lima Junior SA, Oliveira AS (2015) Use of organic compost produced from slaughterhouse waste as fertilizer in soybean and corn crops. Sci Agric. 72: 343-350.

Pavinato PS, Aguiar A, Castro GSA, Crusciol CAC (2009) Boro em arroz de terras altas cultivado em solução nutritiva. Bragantia. 68: 743-751.

Portugal JR, Peres AR, Rodrigues RAF (2015) Aspectos climáticos no feijoeiro. In: Arf O, Lemos LB, Soratto RP, Ferrari S (ed) Aspectos gerais da cultura do feijão Phaseolus vulgaris L. FEPAF, Botucatu, p. 65-75.

Quadros BR, Corrêa CV, Magro FO, Cardoso All (2012) Influência de composto orgânico e fósforo sobre sementes de alface. Semina: Ciênc Agrá. 33: 2511-2518.

Raij B van, Cantarella H, Quaggio JA, Furlani AMC (1997) Recomendações de adubação e calagem para o Estado de São Paulo. 2. ed. Instituto Agronômico e Fundação IAC, Campinas. 285 p.

Ribeiro GJT, Soares AA, Reis MS, Cornélio VMO (2004) Efeito do atraso na colheita e do período de armazenamento sobre o rendimento de grãos inteiros de arroz de terras altas. Ciênc Agrotec. 28: 1021-1030.

Rotili EA, Fidelis RR, Santos MM, Barros HB, Pinto LC (2010) Eficiência do uso e resposta à aplicação de fósforo de cultivares de arroz em solos de terras altas. Bragantia. 69: 705-710.

Santos HG, Jacomine PKT, Oliveira VA, Lumbreras JF, Coelho MR, Almeida JA, Cunha TJF, Oliveira JB (2013) Sistema brasileiro de classificação de solos, 3rd edn. Embrapa, Brasília. 353 p.

Silva EC, Muraoka T, Franzini VI, Sakadevan K, Buetti S, Arf O, Bendassolli JA, Soares FAL (2016) Use of nitrogen from fertilizer and cover crops by upland rice in an Oxisol under no-tillage in the Cerrado. Pesq Agropec Bras. 51: 728-737.

Silva TRB, Soratto RP, Ozeki M, Arf O (2002) Manejo da época de aplicação da adubação potássica em arroz de terras altas irrigado por aspersão em solo de cerrado. Acta Sci. 24: 1455-1460.

Soares AA, Cornélio VMO, Reis MS, Santos PG, Souza MA (2003) Desempenho de linhagens de arroz de terras altas quanto à produtividade de grãos e outras características em Minas Gerais. Rev Ceres. 290: 509-525.

Soares AA, Reis MS, Soares PC (1993) Caiapó, nova opção de arroz de sequeiro para Minas Gerais. Rev Ceres. 40: 513517.

Soares ER, Fernandes R, Londero LS, Galon L, Pires FF, Barbosa MA, Santos DL, Correa SCS, Correa EAS, Santos RC (2015) Fertilization with nitrogen, phosphorus and potassium in upland rice cultivars in the Southern region of Rondônia, Brazil. Am J Plant Sci. 6: 2263-2271. 
Soratto RP, Crusciol CAC, Mello FFC (2010) Componentes da produção e produtividade de cultivares de arroz e feijão em função de calcário e gesso aplicados na superfície do solo. Bragantia. 69: 965-974.

Stone LF, Scivittaro WB, Heineman AB, Silveira PM (2015) Irrigação. In :Borém A, Rangel PHN (eds) Arroz do plantio à colheita. UFV, Viçosa, p.135-160.

Taiz L, Zeiger E (2013) Fisiologia vegetal, 5th edn. Artmed, Porto Alegre. $918 \mathrm{p}$.

Tokura AM, Furtini Neto AE, Curi N, Carneiro LF, Alovisi AA (2007) Silício e fósforo em diferentes solos cultivados com arroz de sequeiro. Acta Sci Agron. 29: 9-16.

Vieira NRA, Carvalho JLV (1999) Qualidade tecnológica. In: Vieira NRA, Santos AB, Sant'Ana EP (ed) A cultura do arroz no Brasil. Embrapa Arroz e Feijão, Santo Antônio de Goiás, p.582-604.

Vieira NRA, Rabelo RR (2006) Qualidade tecnológica. In: Santos AB, Stone LF, Vieira NRA (ed) A cultura do arroz no
Brasil, 2nd edn. Embrapa Arroz e Feijão, Santo Antônio de Goiás, cap. 23, p. 869-900.

Yamashida OM, Isoton RT, Carvalho MAC, Koga PS (2013) Resposta de arroz cv. Primavera à adubação de base no município de Tabaporã-MT. Rev Eletrôn Cient Inov Tecnol. 1: 38-46.

Yoshida S (1981) Fundamentals of rice crop science. IRRI, Los Banõs. 269 p.

Zaratin C, Souza SA, Pantano AC, Sá ME, Arf O, Buzetti S (2004) Efeito de quatro doses de potássio em seis cultivares de arroz de sequeiro irrigados por aspersão. I. Componentes de produção e produtividade. Cient. 32: 115-120. 